\title{
Perception and User Satisfaction on Interior Design of Fadel Muhammad Resources Center (FMRC)
}

\author{
Niken Lastiti Veri Anggaini ${ }^{a} *$ \\ ${ }^{a}$ Brawijaya University, Malang, East Java, Indonesia
}

\section{INFORMASI ARTIKEL}

\section{Article history:}

Date submission : 01 February 2019

First revision : 29 March 2019

Accepted: 20 April 2019

Available online: 26 April 2019

Keywords: library interior design, library user perception, library user satisfaction, public service

\section{ABSTRACT}

User satisfaction can be measured one through the interior design, as the interior design is part of supporting the convenience that must be considered in the library. A good library's interior design will create the impression of comfort and satisfaction to user. This research used quantitative descriptive research with used design interior and user satisfaction concept. It consists of several variables, i.e. space, color, lighting, air circulation, sound, as well as satisfaction. Measurement scale used is Likert scale with a sample of 110 respondents. Results of the study showed that Perception and User Satisfaction of FMRC interior Design can be seen detailed from space variable with a grand mean score (3.32), color variable (3.36), lighting variable (3.31), air circulation variable 3,48), sound variable (3.34), and convenience variables (3.62). It means that perception and user satisfaction of space, color, lighting, and sound variable are included in medium category while air circulation and convenience variable are included in high category.

\section{INTISARI}

Desain interior perpustakaan yang baik akan menciptakan kesan kenyamanan dan kepuasan bagi pemustaka. Penelitian ini menggunakan pendekatan deskriptif kuantitatif dengan menggunakan konsep desain interior dan kepuasan pengguna yang terdiri dari beberapa variabel, yaitu ruang, warna, pencahayaan, sirkulasi air, penataan suara, serta kenyamanan. Skala pengukuran yang digunakan adalah skala Likert dengan sampel sebanyak 110 responden. Hasil penelitian menunjukkan bahwa Persepsi dan Kepuasan Pengguna Desain Interior FMRC dapat dilihat secara rinci dari variabel ruang dengan skor rata-rata $(3,32)$, variabel warna $(3,36)$, variabel pencahayaan $(3,31)$, variabel sirkulasi udara 3,48), variabel suara $(3,34)$, dan variabel kenyamanan $(3,62)$. Kesimpulannya adalah kepuasan pemustaka terhadap variabel ruang, warna pencahayaan dan penataan suara adalah tergolong cukup/ sedang. Sedangkan untuk variabel sirkulasi udara dan kenyamanan tergolong tinggi.

2019 FIA UB. All rights reserved.

\section{Introduction}

Generally, The library is a work unit of an organization, agency, or institution that can stand on its own such as a University library or a part of an organization that is larger than it is like a special library.
The role of the library becomes very important, especially for academics, one of them is the University library, because the University library is the "Heart of the University". As stated in Law No. 43 of 2007, "that the library as a vehicle for lifelong learning develops the

* Corresponding author. Tel.: +62-823-3571-2799; e-mail: nik_fia@yahoo.co.id 
potential of the community to become human beings who are knowledgeable, capable, creative, independent, and become democratic and responsible citizens". The library is a place for providing information, so the library is the goal of students in getting information both in library materials and online.

College library is library that is located in University, subordinate bodies and institutions affiliated with university, with the main goal of helping universities achieve their goals (Sulistyo-Basuki, 1991:198). The purpose of college libraries is to support the performance of universities in conducting education by providing scientific information sources in the library and always serving users (students) while carrying out education in the university. For the purpose to be carried out, the college library must carry out its functions properly.

Information needs and convenience of users must be met in the library, this will lead to satisfaction in the user. The library cannot provide information only and ignores convenience, both of which must be balanced so that the user is truly satisfied. The satisfaction of the user will encourage him to come back to the library. A study by Suyono (1985:86) shows that influencing the use value of the University library is:

a) Facilities and building facilities (5\%);

b) Complete collection (20\%); and

c) Library staff $(75 \%)$.

Quality libraries must pay attention to the physical and activities, based on the physical means and infrastructure in an adequate building or building, while based on activities are activities in work units in the form of storage of collections of library materials which are systematically processed and arranged with certain methods used by users as a source of information. To realize this quality, one of the benchmarks is service to users, both administrative services, circulation services, serial services, reference services, and so on. Facilities and building facilities that are part of interior design receive the smallest value, however interior design has important role in supporting the convenience of the user and needs to be considered, "if the user feels comfortable in the library, the user will be happy to come back to the library" (Lasa, 2007:16).

Interior design is one of the important elements in a library, but in reality, it is often overlooked because of the many factors in the development process. The development of the University library building must be in accordance with the functions and objectives of the University library, so that it can meet the needs of users and also so as not to cause problems. Some problems that will arise due to non-standard library building according to Suyono (1985:10) include:

a) Lack of pleasure;

b) Does not benefit the business to increase the effectiveness and efficiency of work; c) It is not possible to expand the building in its development;

d) Incorrect location causes inaccessibility with the user; and

e) High levels of moisture occur.

Interior design elements that need to be considered in the library building, including five things, namely space, color, lighting, air circulation, and sound system (Lasa, 2005:161). As Ching said (1996:160):

Space is the main thing of a design, element elements that exist in a space such as tables, chairs, stairs, and other interiors will give an appropriate appearance in terms of design, good interior design will determine the space to be habitable, pleasant, and satisfying.

Attention to the interior design of a library will change the image of the library which is seen only as a place for boring books without knowledge of the main functions of the library itself. The current library must develop the services provided, not only personal services carried out by librarians or other staff in the library to the library, but also the services of library buildings that have attractive interior design, this will increase the sense of comfort and satisfaction of the users while in the library. Related to this, the researcher is interested in knowing about perceptions and satisfaction of Fadel Muhammmad Resource Center users (FMRC). This unit was originally called the Learning Resource Center (PSP) which was established in 2009 based on the Dean of Faculty of Administrative Sciences' Regulation, Number: 97 of 2009 concerning the Organization and Work Procedure of the Faculty of Administrative Sciences, Universitas Brawijaya, The Unit functions are as the provision and management of library materials; Utilization of library services; Maintenance and preservation of library materials; and Coordination, evaluation, and collection of library materials. In 2017, FMRC is included in the two best reading rooms in the Universitas Brawijaya sphere besides the Reading Room of the Information and Computer Science Study Program. Related to this, researchers were interested in knowing the level of satisfaction of the users on the FMRC interior design.

\section{Theory}

\subsection{Perception of The Library User}

According to Mulyana (2000:168):

Perception is the core of communication, whereas interpretation (interpretation) is the core of perception, which is identical to the encoding (decoding) in the communication process.

The definition above suggests that a perception is a person's response to a matter, so that the person who can decide whether to respond or ignore it is related to his perception. 
According to Siagian (1995:39), there are several factors that influence a person's perception, namely:

a) Self, attitudes, interests, interests, experiences and expectations in a person influence in shaping perception;

b) Target perceptions, perceptual targets can be people, objects, or events, perceptual targets can affect people who see or experience it; and

c) Factor situation, perception must be contextual meaning that there needs to be a situation where the percept ion arises.

These three factors will influence someone in perceiving something. The same thing can be judged differently by someone because of different perceptions. A person's perceptions can also depend on one's experience of something that is experienced, so that they have different perceptions than those who have not experienced it.

\subsection{Interior Design}

Interior design is the work of architects or designers regarding the design of parts in room, the forms are in accordance with the development of science and technology, so that in the design process always influenced by elements of local geography and habits or social customs embodied in contemporary styles (Pamudji , 1995:2). Interior design is the planning, layout and design of the interior space within buildings. These physical settings satisfy our basic needs for shelter and protection, they require our aspirations and expressions, which we act on, they affect our outlook, mood and personality. The purpose of interior design, therefore, is functional improvement, aesthetic enrichment, and psychological enhancement of interior space (Ching, 2002:46).

Interior design is closely related to architectural science, to meet human needs for art. Humans have beauty, as a form of expression, one of the pouring forms of beauty is through the interior design of a building. "The main factor in the interior planning system always focuses on 3 elements, namely, human, space, and environment" (Pamudji, 1995:5). These three factors must be well studied to create a more robust interior design plan.

The basic elements of design form interior design in a building to have more value, these elements are space, color, air circulation, light, and sound system. These elements will form a mix that makes the interior design of a building more beautiful.

\section{Research Method}

Research conducted using a type of descriptive quantitative research, a research method for the status of a human group, an object, a condition, a system of thought, or a class of events in the present. The measurement scale used a Likert scale. The sample used 110 respondents who are active students of FIA UB. Data analysis techniques used is descriptive statistics that intended to analyze data by describing the results of data that has been processed. The data presented in frequency distribution tables and then described in a narrative manner, which is systematically explained how the results of the variables studied are measured. Then an analysis is carried out, namely criticizing data using theoretical concepts or assumptions.

\section{Results and Discussion}

\subsection{Space Variable}

The result indicators used in the space variable to determine the perceptions and satisfaction of the users of Fadel Muhammad Center's interior design are presented in the following table:

Table 1 Space Variable Frequency Distribution (X1)

\begin{tabular}{|c|c|c|c|c|c|c|c|c|c|c|c|}
\hline \multirow{3}{*}{ Item } & \multicolumn{10}{|c|}{ Aswer Score } & \multirow{3}{*}{ Average } \\
\hline & \multicolumn{2}{|c|}{\begin{tabular}{c|} 
Very \\
satisfied
\end{tabular}} & \multicolumn{2}{|c|}{ Satisfied } & \multicolumn{2}{|c|}{$\begin{array}{c}\text { Quite } \\
\text { satisfied }\end{array}$} & \multicolumn{2}{|c|}{ Unsatisfied } & \multicolumn{2}{|c|}{$\begin{array}{c}\text { Very } \\
\text { dissatisfied }\end{array}$} & \\
\hline & F & $\%$ & F & $\%$ & F & $\%$ & F & $\%$ & $\mathrm{~F}$ & $\%$ & \\
\hline $\mathrm{x} 1.1$ & 9 & 8,18 & 61 & 55,45 & 28 & 25,45 & 12 & 10,91 & 0 & 0 & 3.61 \\
\hline $\mathrm{x} 1.2$ & 9 & 8,18 & 62 & 56,36 & 32 & 29,09 & 7 & 6,36 & 0 & 0 & 3.66 \\
\hline $\mathrm{x} 1.3$ & 4 & 3,64 & 26 & 23,64 & 37 & 33,64 & 39 & 35,45 & 4 & 3,64 & 2.88 \\
\hline $\mathrm{x} 1.4$ & 2 & 1,82 & 34 & 30,91 & 40 & 36,36 & 33 & 30 & 1 & 0,91 & 3.03 \\
\hline $\mathrm{x} 1.5$ & 8 & 7,27 & 45 & 40,91 & 33 & 30 & 23 & 20,91 & 1 & 0,91 & 3.33 \\
\hline $\mathrm{x} 1.6$ & 5 & 4,54 & 48 & 43,64 & 46 & 41,82 & 10 & 9,09 & 1 & 0,91 & 3.42 \\
\hline & & & & & & & & & Grar & Mean & 3.32 \\
\hline
\end{tabular}

Source: Analytical result, 2018

\section{Description:}

X1.1 Reading Room Arrangement

X1.2 Arrangement of collection space

$\mathrm{X} 1.3$ Area of reading room

X1.4 Area of collection space

$X 1.5$ Separation of reading room with other spaces

X1.6 Distance of reading room with other spaces

The mean value of the reading room arrangement item is 3.61. This value is in the high/ large interval class. The library reading room uses a blend system, the reading room and the library collection room are in the same room without any special partition. "The purpose of the system is to make it easier for users to take and return the collection itself in its place" (Saleh \& Komalasari, 2010: 2.33). This turned out to make the users satisfied, this was evidenced by the number of respondents who chose satisfied answers. Although in reality there were 12 respondents who stated they were not satisfied, this was due to the concentration of respondents who were disturbed while in the reading room.

The mean value of the collection room arrangement items is 3.66. This value is at high/ large class intervals. The FMRC collection room is not much different from 
the reading room, because it is located in the same room using the mixing system in its arrangement. The number of respondents stated that they were not satisfied with a number of 7 users. The respondents stated that they were not satisfied because they thought that the collection room could be arranged more varied, so it did not seem boring

The mean area of the reading room is 2.88 . This value is at a sufficient interval. Nevertheless 39 users said that they were dissatisfied with the area of the reading room, because when the situation of the library was crowded, the reading room looked fuller, it was considered uncomfortable for some users.

The mean value of the collection space is 3.03 . This value is in the sufficient/ moderate interval class. The collection room in one room with the reading room has almost the same value. This is because there are not many differences between reading rooms and library collection rooms.

The separator between the reading room and the collection room has a mean value of 3.33 , that is, in the sufficient/ moderate interval class. FMRC implements a system of diffusion in spatial planning, so that there is no skating between the reading room and the collection room.

The mean value of distance of the reading room with the other space is 3.42 , and is in the medium interval class. This value is not much different from the separating item of the reading room with the collection room, because the separator or skating between the reading room and the collection room is only separated by several floors. In general, For the space variable, the grand mean is 3.32 , which means it is in a fairly good category.

\subsection{Color Variable}

The result of color variable can be seen in the following table:

Table 2 Color Variable Frequency Distribution (X2)

\begin{tabular}{|c|c|c|c|c|c|c|c|c|c|c|c|}
\hline \multirow{3}{*}{ Item } & \multicolumn{10}{|c|}{ Answer Score } & \multirow{3}{*}{ average } \\
\hline & \multicolumn{2}{|c|}{$\begin{array}{c}\text { Very } \\
\text { Satisfied } \\
\end{array}$} & \multicolumn{2}{|c|}{ Satisfied } & \multicolumn{2}{|c|}{$\begin{array}{c}\text { Quite } \\
\text { Satisfied } \\
\end{array}$} & \multicolumn{2}{|c|}{ unsatisfied } & \multicolumn{2}{|c|}{\begin{tabular}{|c|} 
Very \\
dissatisfied
\end{tabular}} & \\
\hline & $\mathrm{F}$ & $\%$ & $\mathrm{~F}$ & $\%$ & $\mathrm{~F}$ & $\%$ & $\mathrm{~F}$ & $\%$ & $\mathrm{~F}$ & $\%$ & \\
\hline $\mathrm{x} 2.1$ & 11 & 10 & 39 & 35,45 & 27 & 24,54 & 28 & 25,45 & 5 & 4,54 & 3.21 \\
\hline $\mathrm{x} 2.2$ & 12 & 10,91 & 45 & 40,91 & 40 & 36,36 & 11 & 10 & 2 & 1,82 & 3.49 \\
\hline $\mathrm{x} 2.3$ & 11 & 10 & 48 & 43,64 & 36 & 32,73 & 13 & 11,82 & 2 & 1,82 & 3.48 \\
\hline $\mathrm{x} 2.4$ & 9 & 8,18 & 38 & 34,54 & 39 & 35,45 & 22 & 20 & 2 & 1,82 & 3.27 \\
\hline \multicolumn{11}{|c|}{ Grand Mean } & 3.36 \\
\hline
\end{tabular}

Source: Analytical result, 2018

\section{Description:}

$\mathrm{X} 1.1$ Color of the wall

$\mathrm{X} 1.2$ floor color

$\mathrm{X} 1.3$ Color of the ceiling

$\mathrm{X} 1.4$ Color combinations a) Selection of Wall Colors on FMRC

The mean color of the wall is 3.21 and is at a sufficient/ moderate interval. FMRC uses one color to maintain room harmony and it make some respondent feel bored.

b) Floor Color Selection at FMRC

The mean value of FMRC floor color selection is 3.49 which is in the high / large interval class. The color of the FMRC floor is white with brown shades, the color seems natural so that it is matched with any color that looks harmonious. The floor on the RMRC has the same color on each floor. However, not all of the visitors who were respondents stated that they were satisfied with the color of the floor. 13 respondents said they were not satisfied with the color of the floor because the color was considered ancient and less attractive.

c) FMRC Ceiling Color Selection

The mean value of the ceiling color selection is 3.48 which is at high/ large intervals. From the respondent's data it is known that as many as 13 visitors said they were not satisfied and 2 were very dissatisfied. This is probably due to the white color of the ceiling and the same for each room so that it seems monotonous and boring.

d) FMRC Room Color Combination

The room color combination in the library has a mean value of 3.27 which is at a sufficient class interval. This proves that the color combination that is applied is quite harmonious, although there are some respondents who say they are not satisfied with the difference in colors used.

In overall color variables obtain an average value of 3.36 which means that perceptions and satisfaction of users can be categorized quite well.

\subsection{Air Circulation Variable}

The result of the variable can be seen in table bellow: Table 3 Air Circulation

Variable Frequency Distribution (X3)

\begin{tabular}{|c|c|c|c|c|c|c|c|c|c|c|c|}
\hline \multirow{3}{*}{ Item } & \multicolumn{10}{|c|}{ Answer score } & \multirow{3}{*}{ Average } \\
\hline & \multicolumn{2}{|c|}{$\begin{array}{c}\text { Very } \\
\text { Satisfied }\end{array}$} & \multicolumn{2}{|c|}{ Satisfied } & \multicolumn{2}{|c|}{$\begin{array}{c}\text { Quite } \\
\text { Satisfied }\end{array}$} & \multicolumn{2}{|c|}{ Unsatisfied } & \multicolumn{2}{|c|}{$\begin{array}{c}\text { Very } \\
\text { Dissatisfied }\end{array}$} & \\
\hline & $\mathrm{F}$ & $\%$ & $F$ & $\%$ & $F$ & $\%$ & $F$ & $\%$ & $F$ & $\%$ & \\
\hline $\mathrm{x} 3.1$ & 13 & 11,82 & 37 & 33,64 & 30 & 27,27 & 27 & 24,54 & 3 & 2,73 & 3.27 \\
\hline $\mathrm{x} 3.2$ & 14 & 12,73 & 42 & 38,18 & 29 & 26,36 & 22 & 20 & 3 & 2,73 & 3.38 \\
\hline $\mathrm{x} 3.3$ & 20 & 18,18 & 45 & 40,91 & 34 & 30,91 & 11 & 10 & 0 & 0 & 3.67 \\
\hline $\mathrm{x} 3.4$ & 14 & 12,73 & 48 & 43,64 & 39 & 35,45 & 9 & 8,18 & 0 & 0 & 3.61 \\
\hline \multicolumn{11}{|c|}{ Grand Mean } & 3.48 \\
\hline
\end{tabular}

Source: Analytical result, 2018

Description:

X1.1 Air circulation in the collection room

$\mathrm{X} 1.2$ Circulation in the reading room

$\mathrm{X} 1.3$ Cleanliness of air in the reading room

$\mathrm{X} 1.4$ Cleanliness of air in the collection room 
a) Air Circulation in the Reading Room

The mean value of air circulation in the reading room is 3.27 which is at a sufficient interval class. On these item 27 respondents said they were dissatisfied and 3 respondents said they were very dissatisfied. The number of respondents stated that they were dissatisfied because of the lack of air conditioning facilities in the reading room, so that the visitors felt the air circulation in the reading room was not maximal.

b) Air Circulation in the Collection Room

The mean value of air circulation in the collection room is 3.38 , which is at a sufficient class interval. This value proves that the air circulation in the collection room is quite good even though it still causes user dissatisfaction with the circulation of the library collection room.

c) Air Cleanliness in the Reading Room

The air cleanliness in the reading room has a mean value of 3.67 which is at high / large intervals. and not much different from air circulation items in the reading room. Air circulation affects the cleanliness of the air so that when air circulation is disrupted, the cleanliness of the air is also not good.

d) Air Cleanliness in the Collection Room

Air cleanliness in the collection room has a mean value of 3.61 and is at a high/ large interval. Air cleanliness is very dependent on the good circulation, especially in the collection room where there are many library materials. Library materials contain chemicals that make the air around the smell if it does not get enough air circulation, especially in the old book collection. The lack of air circulation causes poor air cleanliness. Overall for the air circulation variable, the average value is 3.48 which means it is in the good category.

\subsection{Sound Variable}

The result can be seen from the table bellow:

Table 4 Sound Variable Frequency Distribution (X4)

\begin{tabular}{|c|c|c|c|c|c|c|c|c|c|c|c|}
\hline \multirow{3}{*}{ Item } & \multicolumn{10}{|c|}{ Answer Score } & \multirow{3}{*}{ Average } \\
\hline & \multicolumn{2}{|c|}{\begin{tabular}{|c|} 
Very \\
Satisfied \\
\end{tabular}} & \multicolumn{2}{|c|}{ Satisfied } & \multicolumn{2}{|c|}{$\begin{array}{c}\begin{array}{c}\text { Quite } \\
\text { satisfied }\end{array} \\
\end{array}$} & \multicolumn{2}{|c|}{ Unsatisfied } & \multicolumn{2}{|c|}{$\begin{array}{c}\text { Very } \\
\text { dissatisfied }\end{array}$} & \\
\hline & $\mathrm{F}$ & $\%$ & $\mathrm{~F}$ & $\%$ & $\mathrm{~F}$ & $\%$ & $\mathrm{~F}$ & $\%$ & $\mathrm{~F}$ & $\%$ & \\
\hline $\mathrm{x} 4.1$ & 5 & 4,54 & 42 & 38,18 & 47 & 42,73 & 14 & 12,73 & 2 & 1,82 & 3.31 \\
\hline $\mathrm{x} 4.2$ & 7 & 6,36 & 42 & 38,18 & 49 & 44,55 & 8 & 7,27 & 4 & 3,64 & 3.36 \\
\hline & & & & & & Mean & & & & & 3.34 \\
\hline
\end{tabular}

Source: Analytical result, 2018

Description:

X4.1 Placement Speakers

X4.2 Sound management of music/ Music Sound Settings

a) Speaker Placement

Speaker placement gets a value of 3.31 which is at a sufficient interval. Loudspeakers in the library function when there are announcements aimed at users. Because the reading room is not too wide, the placement of loudspeakers placed on the front after the entrance is quite strategic.

b) Music Sound Settings

The music sound settings in the library get a mean value of 3.36 which is at sufficient intervals. Appropriate sound management of music will help the reader to achieve calmness while concentrating, but vice versa when the sound of music that is played improperly will disrupt the concentration of the user. At FMRC there is no music that is played every day, but sometimes there are officials who deliberately play music so the atmosphere is not too quiet, so not all users know that there is music playing in the library room.

Overall, the grand mean for the sound variable at FMRC is 3.34, which means it is in a fairly good category.

\subsection{Lighting Variable}

Lighting is an important element in interior design, in the workspace lighting functions as lighting in doing all activities. Lighting functions to give effect to light in a space when the space does not get natural light, or away from natural light. Designing lighting as part of interior design must also consider many factors, such as the location of the room, the color of the room, the weather, and the equipment that will be needed in the room. The result of the variable can be seen from table bellow:

Table 5 Lighting Variable Frequency Distribution (X6)

\begin{tabular}{|c|c|c|c|c|c|c|c|c|c|c|c|}
\hline \multirow{3}{*}{ Item } & \multicolumn{10}{|c|}{ Answer Score } & \multirow{3}{*}{ Average } \\
\hline & \multicolumn{2}{|c|}{$\begin{array}{c}\text { Very } \\
\text { Satisfied }\end{array}$} & \multicolumn{2}{|c|}{ Satisfied } & \multicolumn{2}{|c|}{$\begin{array}{c}\text { Quite } \\
\text { Satisfied }\end{array}$} & \multicolumn{2}{|c|}{ Unsatisfied } & \multicolumn{2}{|c|}{$\begin{array}{c}\text { Very } \\
\text { Dissatisfied }\end{array}$} & \\
\hline & $\mathrm{F}$ & $\%$ & F & $\%$ & $\mathrm{~F}$ & $\%$ & F & $\%$ & $\mathrm{~F}$ & $\%$ & \\
\hline $\mathrm{X} 5.1$ & 11 & 10 & 39 & 35,45 & 27 & 24,54 & 28 & 25,45 & 5 & 4,54 & 3.21 \\
\hline $\mathrm{X} 5.2$ & 5 & 4,54 & 46 & 41,82 & 48 & 43,64 & 10 & 9,09 & 1 & 0,91 & 3.4 \\
\hline $\mathrm{X} 5.3$ & 12 & 10,91 & 45 & 40,91 & 40 & 36,36 & 11 & 10 & 2 & 1,82 & 3.49 \\
\hline $\mathrm{X} 5.4$ & 5 & 4.54 & 38 & 34.54 & 39 & 35,45 & 26 & 23.64 & 2 & 1.82 & 3.16 \\
\hline \multicolumn{11}{|c|}{ Grand Mean } & 3.31 \\
\hline
\end{tabular}

Source: Analytical result, 2018

\section{Description:}

X6.1 Reading room lighting

X6.2 Lighting collection room

X6.3 Color of reading room lights

X6.4 The color of the collection room lights

a) Brightness of Lighting in the Reading Room

The mean value of the reading room lighting bleeding is 3.21 which is at a sufficient interval. The lighting applied applies natural lighting through windows and also artificial lighting with lights. Lighting that is carried out during the day prioritizes using natural lighting so that many lights are turned off.

b) Lighting Brightness in the Collection Room The mean value for the brightness of the collection room lighting was 3.40 which was at a sufficient interval. Lighting in the collection room is not much different from the reading room, so the number of 
respondents who are dissatisfied with lighting in the collection room is also almost the same as the reading room, because the collection room is in the same room as the reading room.

c) Lamp Color Selection in the Reading Room

The color of the lamp in the reading room has a mean value of 3.49 which is in the high-class interval. The color of the lights in all rooms are the same, white. The lighting method that is applied is by direct lighting method, namely lighting without using an intermediary, so that the user can directly see the lighting.

d) Light Color Selection in the Collection Room

The choice of lamp color in the collection room has the same mean value with the reading color of the reading room lamp which is 3.16 which is in a sufficient class interval.

Overall for the lighting variable obtained an average value of 3.31 which means that the perception and satisfaction of users of lighting at FMRC is sufficient. This is due to the use of natural light and artificial light coming from windows and lights.

\subsection{Variables Convenience}

Convenience variable was used to know the user satisfaction of interior design that showed in following table.

Table 6 Variable Frequency Distribution of 'Convenience' variable (X5)

\begin{tabular}{|c|c|c|c|c|c|c|c|c|c|c|c|}
\hline \multirow{3}{*}{ Item } & \multicolumn{10}{|c|}{ Answer score } & \multirow{3}{*}{ Averag } \\
\hline & \multicolumn{2}{|c|}{$\begin{array}{c}\text { Very } \\
\text { Satisfied }\end{array}$} & \multicolumn{2}{|c|}{ Satisfied } & \multicolumn{2}{|c|}{$\begin{array}{c}\text { Quite } \\
\text { Satisfied } \\
\end{array}$} & \multicolumn{2}{|c|}{ Unsatisfied } & \multicolumn{2}{|c|}{\begin{tabular}{|c} 
Very \\
Dissatisfied
\end{tabular}} & \\
\hline & $\mathrm{F}$ & $\%$ & $F$ & $\%$ & $\mathrm{~F}$ & $\%$ & $\mathrm{~F}$ & $\%$ & $\mathrm{~F}$ & $\%$ & \\
\hline X6.1 & 6 & 5,45 & 29 & 26,36 & 54 & 49,09 & 20 & 18,18 & 1 & 0,91 & 3.17 \\
\hline $\mathrm{X} 6.2$ & 9 & 8,18 & 38 & 34,54 & 50 & 45,45 & 12 & 10,91 & 1 & 0,91 & 3.38 \\
\hline $\mathrm{X} 6.3$ & 4 & 3,64 & 28 & 25,45 & 38 & 34,54 & 38 & 34,54 & 2 & 1,82 & 2.94 \\
\hline $\mathrm{X} 6.4$ & 30 & 27,27 & 41 & 37,27 & 29 & 26,36 & 9 & 8,18 & 1 & 0,91 & 3.82 \\
\hline $\mathrm{X} 6.5$ & 28 & 25,45 & 47 & 42,73 & 28 & 25,45 & 6 & 5,45 & 1 & 0,91 & 3.86 \\
\hline $\mathrm{X} 6.6$ & 28 & 25,45 & 55 & 50 & 17 & 15,45 & 7 & 6,36 & 3 & 2,73 & 3.89 \\
\hline $\mathrm{X} 6.7$ & 19 & 7,27 & 53 & 48,18 & 27 & 24,54 & 10 & 9,09 & 1 & 0,91 & 3.72 \\
\hline $\mathrm{X} 6.8$ & 14 & 12,72 & 51 & 46,36 & 35 & 31,82 & 8 & 7,27 & 2 & 1,82 & 3.61 \\
\hline $\mathrm{X} 6.9$ & 27 & 24,54 & 51 & 46,36 & 27 & 24,54 & 4 & 3,64 & 1 & 0,91 & 3.9 \\
\hline $\mathrm{X} 6.10$ & 27 & 24,54 & 51 & 46,36 & 28 & 25,45 & 3 & 2,73 & 1 & 0,91 & 3.91 \\
\hline $\mathrm{X} 6.11$ & 17 & 15,45 & 49 & 44,55 & 31 & 28,18 & 11 & 10 & 2 & 1,82 & 3.62 \\
\hline $\mathrm{X} 6.12$ & 15 & 13,64 & 49 & 44,55 & 33 & 30 & 10 & 9,09 & 3 & 2,73 & 3.57 \\
\hline \multicolumn{11}{|c|}{ Grand Mean } & 3.62 \\
\hline
\end{tabular}

Source: Analytical result, 2018

Description:

X5.1 Physical condition of the building

X5.2 Condition of equipment in the library

X5.3 Building area according to the number of students

$\mathrm{X} 5.4$ Calmness of reading room

X5.5 Calmness of collection space

X5.6 Libraries are used as alternative learning

X5.7 Comfort of the reading room

X5.8 Comfort of the collection room

X5.9 Cleanliness of the reading room

X5.10 Cleanliness of the collection room
X.5.11 Condition of the reading room from outside sound

X5.12 Condition of collection room from outside sound

a) Building Physical Condition

The physical condition of the building gets a mean of 3.17 which means that the value is at sufficient intervals. RMRC occupies the new building in 2015, only the size of the room is not too large when compared to the current number of active FIA UB students.

b) Physical Condition of FMRC Equipment

The physical condition of library equipment has a mean value of 3.38 which is at sufficient intervals. There are still many users who are not satisfied with the physical condition of library equipment making the mean value of the item is medium. Users want more updates on equipment in the library.

c) FMRC Building Area

The library building area has a mean value of 2.94 which is at a moderate interval. The library's building area is $5500 \mathrm{~m} 2$, however, the vast library is able to accommodate active library members. Some respondents stated that the size of the library was lacking, because when the library was crowded the library looked full so that the visitors were not free to be in the library.

d) Calmness of the FMRC Reading Room

The quiet of the reading room has a mean value of 3.82 which is at high/ large intervals. Quietness in the reading room will affect the satisfaction of visitors to the library. The FMRC reading room is in one room with a co-space with a distance that is not too far away, so that visitors who are in the reading room are sometimes disturbed by activities and sounds from the collection room, or other spaces.

e) Calmness of the FMRC Collection Room

The quiet of the collection room has a mean value of 3.86 at high/ large intervals. Unlike the reading room, in the collection room the mean value is greater, because the user needs better concentration when in the reading room than when in the collection room.

f) Library as a Learning Alternative

The mean value in the library as a learning alternative is quite high at 3.89 and is at a high interval. However, there are some users who say they are not satisfied with the library as an alternative place of learning because they are considered not too broad and prefer to look for references via the internet on a notebook or cellphone.

g) Comfort of FMRC Reading Room

The comfort of the reading room has a high mean value of 3.72 users who feel that the reading room is quite comfortable to use alone or in groups while in the reading room. This is supported by the 
arrangement of tables and chairs according to the needs of the users.

h) Comfort of Collection Room

The mean value of the comfort of the collection room is 3.61 at high intervals, proving that the collection room is quite comfortable for the user, although some respondents stated that they were not satisfied with the security of the collection room. User dissatisfaction due to the difficulty of finding the desired library material, and the large number of old and foreign language library materials.

i) Cleanliness of FMRC Reading Room

The cleanliness of the reading room has a mean value of 3.9, which means there is a high interval. The library user says that the reading room is clean, even though sometimes there are leftovers from the remaining candy packs. FMRC regulations prohibit libraries from carrying food into libraries, but there are some users who violate and leave the leftovers in the library, so other visitors feel that library cleanliness is poorly maintained.

j) Cleanliness of the FMRC Collection Room

The mean cleanliness of the collection room is 3.91 not much different from the mean value of reading room cleanliness. The reading room and collection room are in the same room, this is what causes the mean value of the cleanliness of the reading room and collection space is almost the same.

k) Conditions in the Reading Room of the Outer Sound The condition of the reading room of the outside sound has a mean value of 3.62 at high intervals. Although many respondents expressed satisfaction, there were some respondents who were not satisfied with the condition.

1) Conditions in the Collection Room of Outer Sounds

The condition of the collection room from outside sounds has a mean value of 3.57 at high intervals. Similar to the condition of the reading room from outside sound, the same conditions are also found in the collection room, where the sound from the outside is not too audible so as not to interfere with the activity inside.

Overall for the convenience variable, the grand mean is 3.62 which means that the perception and satisfaction of the users of FMRC in terms of comfort is very good.

\section{Conclusion}

After conducting research with the title of Perception and Satisfaction of Users of FMRC Interior Design, the conclusions were obtained about how the perceptions of users of interior design at FMRC are as follows:

a) The value of the grand mean of the overall space variable is 3.32 which is in a sufficient interval class. This value shows that overall the respondents were quite satisfied with the reading room and collection room in the library;

b) In the area of the reading room and collection space the space variable has the smallest mean value among the other indicators in the space variable because the reader considers the space too close, so that when the library is crowded, the condition of the library is disturbed;

c) The color variable gets a grand mean of 3.36 which is in the adequate level. Overall the respondents stated that they were quite satisfied with the colors used;

d) The lighting variable has a grand mean value of 3.31, is at a sufficient interval. This value indicates that more respondents are satisfied with lighting;

e) The existence of respondents who expressed dissatisfaction with the lighting at FMRC was on reading room lighting items and collection rooms because some respondents considered the lighting at FMRC to be less than optimal, so that many spaces that were not reachable by window light and did not get enough light from the lights so impressed dark;

f) Variable air circulation has a grand mean value of 3.48 , which is at high intervals, so it can be concluded that air circulation in the reading room and collection room is good;

g) Sound variable has a grand mean value of 3.34. In the sound variable, it can be concluded that the Respondent feels quite satisfied with the sound system in FMRC; and

h) The satisfaction variable measured from the comfort variable has the highest grand mean value of 3.62 which is in the high interval class. This value shows the user is satisfied with the library. This makes the perception of the library user good, which indicates that the library is conveniently located in the library.

From the result oh the study, the suggestion recommended in this research are:

a) The need for additional reading room and collection space of FMRC in accordance with the provisions of library regulations so that it does not seem narrow and the space between spaces is wider and the visitors can be more flexible in conducting learning activities;

b) The need for additional equipment facilities and room facilities specifically for people with disabilities and creativity; and

c) Give a touch of other colors to the walls, floor and ceiling so as not to seem monotonous and boring.

\section{References}

Ching, Franchis D.K. (1996). Ilustrasi Desain Interior. Jakarta: Erlangga.

Ching, Franchis D.K. (2002). Achitectur, Space and Order. New York: Maxmillan Publishing Company. 
Lasa HS. (2005). Manajemen Perpustakaan. Jakarta: Gama Media.

(2007). Manajemen Perpustakaan Sekolah. Jakarta: Gama Media.

Mulyana, Dedy. (2000). Ilmu Komunikasi, Pengantar. Bandung: Remaja Rosadakarya.

Pamudji. (1995). Perancangan Tata Ruang dalam Desain Interior. Jakarta: Penerbit Universitas Trisakti.

Saleh, Abdul Rahman., \& Komalasari, Rita. (2010). Manajemen Perpustakaan. Penerbit Universitas Terbuka, Jakarta.

Siagian, Sondang. (1995). Teori Motivasi dan Aplikasinya. Jakarta: PT. Rineka Cipta.

Sulistyo-Basuki. (1991). Pengantar Ilmu Perpustakaan. Jakarta: Gramedia.

Suyono, Trimo. (1985). Pedoman Pelaksanaan Perpustakaan. Bandung: Remadja. 